\title{
Advances in Understanding the Actions of Nitrous Oxide
}

\author{
Dimitris E. Emmanouil, DDS, MS, PhD, ${ }^{*}$ and Raymond M. Quock, PhD $\dagger$ \\ *Department of Pediatric Dentistry, School of Dentistry, Athens University, Athens, Greece, and †Department of Pharmaceutical \\ Sciences, College of Pharmacy, Washington State University, Pullman, Washington
}

Nitrous oxide $\left(\mathrm{N}_{2} \mathrm{O}\right)$ has been used for well over 150 years in clinical dentistry for its analgesic and anxiolytic properties. This small and simple inorganic chemical molecule has indisputable effects of analgesia, anxiolysis, and anesthesia that are of great clinical interest. Recent studies have helped to clarify the analgesic mechanisms of $\mathrm{N}_{2} \mathrm{O}$, but the mechanisms involved in its anxiolytic and anesthetic actions remain less clear. Findings to date indicate that the analgesic effect of $\mathrm{N}_{2} \mathrm{O}$ is opioid in nature, and, like morphine, may involve a myriad of neuromodulators in the spinal cord. The anxiolytic effect of $\mathrm{N}_{2} \mathrm{O}$, on the other hand, resembles that of benzodiazepines and may be initiated at selected subunits of the $\gamma$-aminobutyric acid type A $\left(\mathrm{GABA}_{\mathrm{A}}\right)$ receptor. Similarly, the anesthetic effect of $\mathrm{N}_{2} \mathrm{O}$ may involve actions at $\mathrm{GABA}_{\mathrm{A}}$ receptors and possibly at $\mathrm{N}$-methyl-D-aspartate receptors as well. This article reviews the latest information on the proposed modes of action for these clinical effects of $\mathrm{N}_{2} \mathrm{O}$.

Key Words: Nitrous oxide; Pharmacology; Anesthesia; Analgesia; Anxiolysis.

$\mathbf{N}$ itrous oxide $\left(\mathrm{N}_{2} \mathrm{O}\right)$ was discovered in 1793 by the English scientist Joseph Priestley, who also discovered oxygen $\left(\mathrm{O}_{2}\right)$. In 1799, Sir Humphrey Davy administered $\mathrm{N}_{2} \mathrm{O}$ to visitors at the Pneumatic Institute and gave it for the first time the term "laughing gas." He astutely noted the analgesic effects of the gas and even predicted its application in suppression of pain during surgical procedures. However, for the next 40 years or so, the primary use of $\mathrm{N}_{2} \mathrm{O}$ was for recreational enjoyment and public shows. $\mathrm{N}_{2} \mathrm{O}$ found a more scientific use as an anesthetic in clinical dentistry and medicine in the early 1840s. Horace Wells, an American dentist, had one of his own teeth extracted while inhaling $\mathrm{N}_{2} \mathrm{O}$ - the first demonstration of clinical anesthesia. There followed a period of wide clinical use of $\mathrm{N}_{2} \mathrm{O}$ for dental anesthesia, which, unfortunately, was followed by a period of abandonment when it was recognized that the high concentrations required for anesthesia frequently placed the patient at risk of severe hypoxia and death from as-

Received May 11, 2006; accepted for publication September 9, 2006.

Address correspondence to Dr Dimitris Emmanouil, Department of Pediatric Dentistry, Dental School, University of Athens, 2 Thivon str., Athens 115 27, Greece; emmand@dent.uoa.gr. phyxiation. Although the specific manner of use of $\mathrm{N}_{2} \mathrm{O}$ has changed considerably in the past 150 years, it remains today the most widely used of all general anesthetic agents and plays an all-important role in both dental and medical practice. The introduction of anesthesia through $\mathrm{N}_{2} \mathrm{O}$ is considered a great achievement in dentistry, comparable to the discovery of local anesthesia and the fluoridation of water. ${ }^{1,2}$

Today the common medical uses of $\mathrm{N}_{2} \mathrm{O}$ include balanced anesthesia during surgery, wherein $\mathrm{N}_{2} \mathrm{O}$ is frequently combined with other general anesthetic drugs and nonanesthetic preoperative drugs, and analgesia for the relief of pain in clinical as well as emergency situations. There are significant nonmedical uses of $\mathrm{N}_{2} \mathrm{O}$ as well. In industry, $\mathrm{N}_{2} \mathrm{O}$ is used as an oxidizer in atomic absorption spectrometry and in the manufacture of semiconductors. In the dairy industry, $\mathrm{N}_{2} \mathrm{O}$ is used as a bacteriostatic, tasteless, odorless food processing propellant. $\mathrm{N}_{2} \mathrm{O}$ is also injected into the air intake of car engines by racing enthusiasts to boost horsepower. $\mathrm{N}_{2} \mathrm{O}$ is also used to prepare divers for deep dives because it mimics the disorientation and behavioral changes of decompression illness (the "bends") when a diver surfaces from the depths too rapidly. 
For nearly 150 years since its discovery, $\mathrm{N}_{2} \mathrm{O}$ has been used by clinicians without a clear knowledge of its mechanisms of action. Only over the last 20-30 years has there been any significant research elucidating the mechanisms of the analgesic, antianxiety, and anesthetic effects of $\mathrm{N}_{2} \mathrm{O}$. In 1985, Eger published the first comprehensive book on $\mathrm{N}_{2} \mathrm{O}$, gathering all available information up to that time and providing an excellent summary of clinical and research issues. ${ }^{3}$ Since then, a large amount of research has been added, clarifying a number of issues about the actions of $\mathrm{N}_{2} \mathrm{O}$. A Medline search for research manuscripts on the pharmacology of $\mathrm{N}_{2} \mathrm{O}$ revealed 2439 articles between 1940 and 1980; a similar search conducted recently uncovered 5801 articles between 1981 and 2006.

This timely review will update readers on the current state of knowledge of the pharmacokinetic and pharmacodynamic aspects of $\mathrm{N}_{2} \mathrm{O}$. The relevant clinical uses of $\mathrm{N}_{2} \mathrm{O}$ as an analgesic, anxiolytic, and anesthetic drug will be explored.

\section{ANALGESIA}

Subanesthetic concentrations of $\mathrm{N}_{2} \mathrm{O}$ produce only analgesic and anxiolytic effects without unconsciousness. ${ }^{4}$ Analgesic $\mathrm{N}_{2} \mathrm{O}$ has a long history of use in obstetrics for relief of labor pain. ${ }^{5} \mathrm{~N}_{2} \mathrm{O}$ is also used for self-administered analgesia in cancer patients, ${ }^{6}$ preemptive analgesia, ${ }^{7}$ and to alleviate pain and discomfort associated with a number of medical procedures, including intra-articular drug injection, ${ }^{8}$ peripheral intravenous cannulation, ${ }^{9}$ sigmoidoscopy, ${ }^{10}$ colonoscopy, ${ }^{11}$ ophthalmologic procedures, ${ }^{12}$ and biopsy procedures. ${ }^{13}$ In Europe, Entonox (BOC Group), a 50\% $\mathrm{N}_{2} \mathrm{O}: 50 \%$ oxygen mixture, is widely used in emergency medical care of patients in accident scenes and during ambulance transportation. ${ }^{14-16}$

The mechanism of the analgesic effect of $\mathrm{N}_{2} \mathrm{O}$ is gradually being clarified through elucidation of the antinociceptive effect of $\mathrm{N}_{2} \mathrm{O}$ in animals. Because animals are unable to report a reduction in sensation of pain, analgesia is more properly determined in animals as antinociception or a diminished responsiveness to a noxious stimulus.

\section{The Opioid Hypothesis of $\mathrm{N}_{2} \mathrm{O}$ Antinociceptive Action}

It was as early as 1943 when the analgesic effect of $\mathrm{N}_{2} \mathrm{O}$ was judged to be comparable to that of opioid analgesic drugs- $30 \%$ of $\mathrm{N}_{2} \mathrm{O}$ was deemed to be equieffective as 10-15 mg of morphine. ${ }^{17}$ It was not until the mid1970 s that it was first reported that $\mathrm{N}_{2} \mathrm{O}$-induced antinociception in mice and rats was sensitive to blockade by the narcotic antagonist naloxone. ${ }^{18,19} \mathrm{~N}_{2} \mathrm{O}$-induced analgesia in human subjects was also antagonized by naloxone. ${ }^{20-23}$

A large number of studies have established an important role for opioid receptors in the periaqueductal gray (PAG) area of the midbrain in pain modulation. ${ }^{24}$ The $\mathrm{N}_{2} \mathrm{O}$-induced analgesic effect could be completely ablated after lesioning the PAG in the rat ${ }^{25}$ or following microinjection of opioid antagonists into the PAG. ${ }^{26-28}$

Although these results clearly implicate opioid receptors in mediation of $\mathrm{N}_{2} \mathrm{O}$-induced antinociception and analgesia, it is appreciated today that opioid receptors are not a monolithic species. There are multiple opioid receptors that are capable of mediating pain relief, and the specific subtypes of opioid receptors that mediate the antinociceptive effects of $\mathrm{N}_{2} \mathrm{O}$ appear to depend on various factors including the species and/or strain, the regions of the brain, and the experimental noxious stimulus. ${ }^{29}$ In the mouse abdominal constriction test, $\mathrm{N}_{2} \mathrm{O}$ antinociception was unaffected by either $\mu$ or $\delta$ opioid antagonists but was sensitive to blockade by drugs with antagonist properties at $\kappa$ opioid receptors. ${ }^{30,31} \mathrm{~A} \kappa$ opioid ligand also protected $\mathrm{N}_{2} \mathrm{O}$ antinociception in mice from antagonism by an irreversible, nonselective opioid antagonist. ${ }^{32}$ The $\kappa$ opioid receptor subtype appears to be involved at both the supraspinal and spinal cord levels in suppression of chemical noxious stimulation, ${ }^{33}$ which is supported by observations that $\mathrm{N}_{2} \mathrm{O}$-induced antinociception was antagonized by supraspinal and spinal pretreatment with antisera against the endogenous $\kappa$ opioid ligand, dynorphin (DYN). ${ }^{34,35}$ In the rat hot plate test, $\mu$ and $\varepsilon$ opioid receptor subtypes appear to perform a main function at the supraspinal level, as demonstrated by the effectiveness of $\mu$ and $\epsilon$ opioid antagonists to reduce $\mathrm{N}_{2} \mathrm{O}$-induced antinociception. ${ }^{26}$

The opioid connection was further strengthened by reports of morphine-tolerant animals being cross-tolerant to $\mathrm{N}_{2} \mathrm{O} \cdot{ }^{19,36}$ The fact that cross-tolerance was unilateral in that $\mathrm{N}_{2} \mathrm{O}$-tolerant animals were not cross-tolerant to morphine led Berkowitz et al to hypothesize that $\mathrm{N}_{2} \mathrm{O}$ might work through stimulating the neuronal release of endogenous opioid peptides. ${ }^{36}$ Chronic treatment with morphine results in desensitization of opioid receptors and/or signal transduction mechanisms, hence resulting in cross-tolerance to $\mathrm{N}_{2} \mathrm{O}$, which relies on the same opioid receptors. Chronic treatment with $\mathrm{N}_{2} \mathrm{O}$ results in a tolerance that is attributable to excessive depletion of endogenous opioid peptide stores, such that a subsequent exposure to $\mathrm{N}_{2} \mathrm{O}$ is unable to release sufficient quantities of opioid peptides to cause antinociception. The chronic exposures to $\mathrm{N}_{2} \mathrm{O}$ in these tolerance investigations were not sufficient for inducing the same changes at the receptor and/or signal levels that were observed in the chronic morphine studies. 
The first chemical evidence for $\mathrm{N}_{2} \mathrm{O}$-induced release of opioid peptides did not emerge until nearly 10 years following the first report of naloxone antagonism of $\mathrm{N}_{2} \mathrm{O}$-induced antinociception. Exposure to $75 \% \mathrm{~N}_{2} \mathrm{O}$ for 60 minutes increased by 2 -fold the amount of immunoreactive methionine-enkephalin (ME) in fractions of perfusate collected from ventricular-cisternally perfused rats. ${ }^{37}$ At the end of $\mathrm{N}_{2} \mathrm{O}$ exposure, the levels of immunoreactive ME returned to baseline. This led to the conclusion that $\mathrm{N}_{2} \mathrm{O}$ was capable of inducing the neuronal release of either $\mathrm{ME}$ itself or a ME-like peptide in the rat brain. Later studies also showed that $\mathrm{N}_{2} \mathrm{O}$ increased $\beta$-endorphin concentrations in the arcuate propriomelanocortin neuronal system in rats, ${ }^{38}$ a result that was reproduced in an in vitro system..$^{39}$

The most extensive studies have been conducted in the mouse abdominal constriction test. The opioid peptide released by $\mathrm{N}_{2} \mathrm{O}$ was identified as DYN in experiments utilizing rabbit antisera against rat opioid peptides. $\mathrm{N}_{2} \mathrm{O}$ antinociception was antagonized by intracerebroventricular pretreatment with antisera against $\mathrm{DYN}_{1-8}$ and $\mathrm{DYN}_{1-13}$ but not ME or $\beta$-endorphin. ${ }^{34}$ In a subsequent study, it was discovered that $\mathrm{N}_{2} \mathrm{O}$ antinociception was also sensitive to antagonism by intrathecal pretreatment with antisera to $\mathrm{DYN}_{1-8}, \mathrm{DYN}_{1-13}$, and ME. ${ }^{35}$ These findings are consistent with studies reporting that activation of supraspinal $\mathrm{\kappa}$ opioid receptors causes a release of ME in the spinal cord. ${ }^{40}$ Therefore, in this one experimental model, it appears that $\mathrm{N}_{2} \mathrm{O}$ evokes its antinociceptive effect through the supraspinal release of various DYNs, which are the endogenous ligands of $\kappa$ opioid receptors, and spinal release of DYNs and ME.

\section{Involvement of Nitric Oxide in $\mathrm{N}_{2} \mathrm{O}$ Antinociception}

Nitric oxide (NO) is a naturally occurring gas that only recently has been recognized as an endogenous biological regulator of great significance. Science magazine declared NO as "The Molecule of the Year" for 1992.41 There is evidence that NO released from nitrergic neurons seems to regulate the release of a variety of transmitters (acetylcholine, catecholamines, excitatory and inhibitory amino acids, serotonin, histamine, and adenosine) in the brain..$^{42} \mathrm{~N}_{2} \mathrm{O}$ antinociception was antagonized in dose-related fashion by a series of L-arginine analogs that competitively inhibit NO synthase (NOS), including $\mathrm{L}-\mathrm{N}^{\mathrm{G}}$-nitro arginine. This antagonism was stereoselectively reversed by administration of L-arginine but not $\mathrm{D}$-arginine. L-N ${ }^{\mathrm{G}}$-nitro arginine had no such interaction with morphine or the $\mathrm{\kappa}$ opioid agonist U$50,488 \mathrm{H} .{ }^{43}$ Later studies demonstrated that $\mathrm{N}_{2} \mathrm{O}$-induced antinociception was more specifically antago- nized by pretreatment with a selective inhibitor of neuronal $\mathrm{NOS}^{44}$ or an antisense oligodeoxynucleotide directed against neuronal NOS. ${ }^{45}$ Nitric oxide also appears to play a key role in opioid peptide release. A tangential study was designed to test this hypothesis. If $\mathrm{N}_{2} \mathrm{O}$ antinociception in the abdominal constriction model is caused by stimulated release of DYNs, which then activate $\kappa$ opioid receptors, and if NO appears not to influence $\kappa$ opioid receptor or signal transduction, then it is possible that NO influences the stimulated release of DYNs. ${ }^{46}$ (See Figure 1)

Further evidence of the importance of $\mathrm{NO}$ in $\mathrm{N}_{2} \mathrm{O}$ antinociception emerged from experiments in inbred mouse strains. $\mathrm{N}_{2} \mathrm{O}$ evoked a concentration-dependent antinociception in various mouse strains, including the C57BL/6 inbred strain, but DBA/2 inbred mice exposed to identical levels of $\mathrm{N}_{2} \mathrm{O}$ responded with only a weak antinociceptive effect. ${ }^{47,48}$ When mice were exposed to $\mathrm{N}_{2} \mathrm{O}$, there was increased whole-brain NOS activity - as quantified by radioconversion of $\left[{ }^{14} \mathrm{C}\right] \mathrm{L}-\mathrm{ar}-$ ginine to $\left[{ }^{14} \mathrm{C}\right] \mathrm{L}$-citrulline-in the C57BL/6 mouse but not the DBA/2 mouse. ${ }^{49}$ This apparent correlation between antinociceptive responsiveness and increase in NOS enzyme activity was recently confirmed in mice selectively bred for low sensitivity to $\mathrm{N}_{2} \mathrm{O}$-induced antinociception. ${ }^{50}$

Quantitative trait loci analysis in C57BL/6 and DBA/

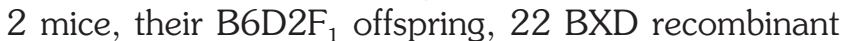
inbred strains (derived from the progenitors), and 600 offspring bred from the $\mathrm{F}_{2}$ generation identified 2 markers from chromosomes 2 and 5 that were significantly correlated with $\mathrm{N}_{2} \mathrm{O}$ antinociception and 1 marker from chromosome 18 that was suggestive. ${ }^{48,51}$ It is significant that the genetic control of neuronal NOS is localized to mouse chromosome 5 in the same vicinity as one of the significant markers in the quantitative trait loci analysis. ${ }^{52}$ Determination of other NOS-related factors may also be located in the same area of the chromosome.

Therefore, it seems likely that in the mouse abdominal constriction model, NO provokes the release of endogenous opiates (DYN peptides) playing a mediatory role in the antinociceptive effect of $\mathrm{N}_{2} \mathrm{O}$. The location of the nerve terminals from which DYN is released and the location of the $\mathrm{\kappa}$ opioid receptors have not been determined.

\section{Descending Pathways Activated by $\mathrm{N}_{2} \mathrm{O}$}

Fujinaga and Maze ${ }^{53}$ hypothesized that the release of endogenous opioid peptides and the subsequent stimulation of opioid receptors activate descending pathways that modulate nociceptive processing in the spinal cord. There are several steps to this process, as demonstrated by a series of elegant studies conducted in rats. A nor- 


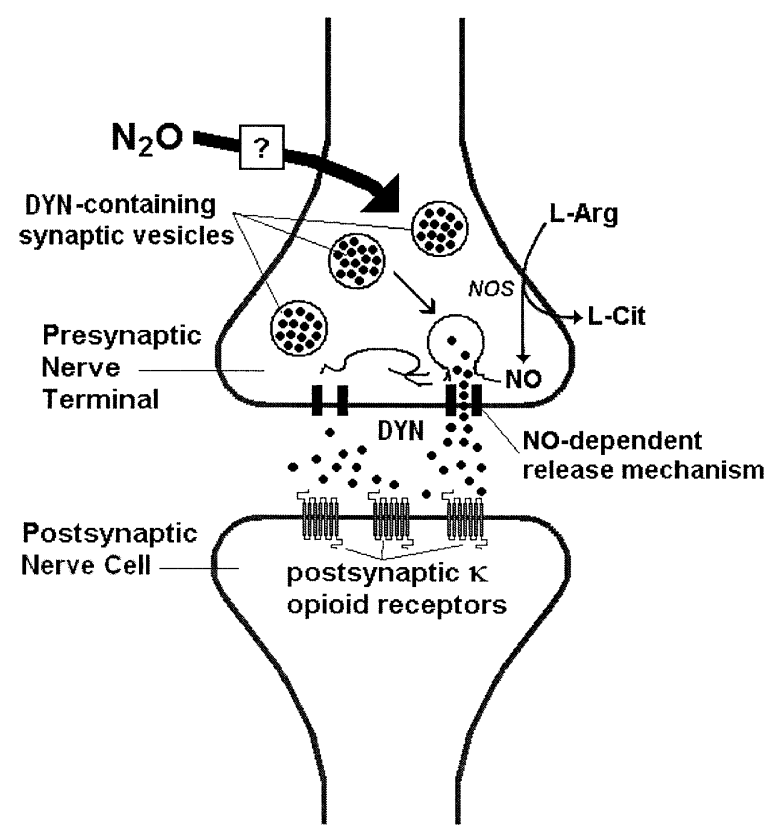

Figure 1. Mechanism of $\mathrm{N}_{2} \mathrm{O}$-induced analgesia. $\mathrm{N}_{2} \mathrm{O}$ is thought to stimulate the neuronal release of endogenous opioid peptide or dynorphins (DYNs); the molecular aspects of how $\mathrm{N}_{2} \mathrm{O}$ initiates this process are as yet unknown. The presynaptic nerve terminal takes up L-arginine (L-Arg), which is converted by the enzyme nitric oxide synthase (NOS) to Lcitrulline (L-Cit) and nitric oxide (NO). NO appears to be involved in the stimulated release of DYNs. DYNs traverse the synaptic cleft and activate postsynaptic opioid receptors, which belong to the 7-transmembrane-spanning, $G$ proteincoupled superfamily of receptors.

adrenergic pathway is the most important descending pathway; however, it is under tonic inhibition by a $\gamma^{-}$ aminobutyric acid (GABA)-ergic pathway in the A7 area of the pons. The stimulation of opioid receptors by $\mathrm{N}_{2} \mathrm{O}$-released opioid peptides inhibits the inhibitory GABA-ergic pathway, thus causing disinhibition of the descending noradrenergic pathway.

This hypothesis is borne out by the experimental evidence. Transection of the spinal cord prevents the antinociceptive response to $\mathrm{N}_{2} \mathrm{O} .{ }^{54}$ Microinjection of opioid receptor antagonists into the PAG effectively blocks the antinociceptive effect of $\mathrm{N}_{2} \mathrm{O},{ }^{26-28}$ whereas opioid antagonists administered intrathecally have no effect. ${ }^{55}$ Conversely, intrathecal but not supraspinal administration of $\alpha_{2}$ adrenergic receptor blockers antagonizes $\mathrm{N}_{2} \mathrm{O}$-induced antinociception. ${ }^{55}$ Studies in transgenic mice indicate that $\alpha_{2 \mathrm{~B}}$ and/or $\alpha_{2 \mathrm{C}}$ but not $\alpha_{2 \mathrm{~A}}$ adrenergic receptors are responsible for the antinociceptive effect of $\mathrm{N}_{2} \mathrm{O} .{ }^{56}$ Alpha $_{1}$ adrenergic receptors have also been implicated in $\mathrm{N}_{2} \mathrm{O}$-induced antinociception. ${ }^{57}$ Depletion of norepinephrine in the spinal cord antagonizes the antinociceptive effect of $\mathrm{N}_{2} \mathrm{O} .{ }^{54}$
Descending noradrenergic inhibitory neurons are not functional at birth and take at least 3 weeks to fully develop in rats. ${ }^{58}$ It has been suggested that the central nervous system of a 3-week-old rat is equivalent to that of a human at the toddler stage. ${ }^{59}$ This may explain experimental observations that rats do not exhibit sensitivity to the antinociceptive effects of $\mathrm{N}_{2} \mathrm{O}$ before 4 weeks of age. ${ }^{60,61}$ Although the sequential neurological developments in rat and human central nervous systems are not totally comparable, these results suggest that $\mathrm{N}_{2} \mathrm{O}$ may not be efficacious as an analgesic agent in early childhood.

The disinhibited noradrenergic pathway appears to modulate spinal nociceptive processing by 2 divergent pathways (Figure 2). One population of $\alpha_{2}$ adrenergic receptors is located on second-order neurons in the pain pathway, whereas the other is located on inhibitory GABA interneurons in the spinal cord. This dual involvement of GABA as pronociceptive supraspinally and antinociceptive spinally is consistent with experimental findings. $\mathrm{N}_{2} \mathrm{O}$-induced antinociception was antagonized by intracerebroventricular administration of muscimol, a GABA type A $\left(\mathrm{GABA}_{\mathrm{A}}\right)$ agonist, and intrathecal administration of gabazine, a $\mathrm{GABA}_{\mathrm{A}}$ antagonist. ${ }^{62}$

Immunohistochemical and in situ hybridization identification of the immediate early gene $c$-fos or the FOS protein that it encodes can be used to map functional activation in discrete brain regions of rats following physiological, pharmacological, or psychological stimulation. $\mathrm{N}_{2} \mathrm{O}$ exposure increases c-Fos expression in the pontine noradrenergic nuclei as well as the spinal cord. ${ }^{63} \mathrm{~N}_{2} \mathrm{O}$-induced c-Fos expression in the spinal cord was colocalized to cells containing the rate-limiting enzyme in the synthesis of GABA. ${ }^{64}$ Expression of c-Fos in these regions was antagonized by opioid receptor blockade and also by stimulation of $\mathrm{GABA}_{\mathrm{A}}$ receptors in the PAG. Microinjection of opioid antagonist and GA$\mathrm{BA}_{\mathrm{A}}$ agonist into the pontine A7 nuclei also inhibited $\mathrm{N}_{2} \mathrm{O}$-induced expression of c-Fos in the spinal cord as well as attenuate $\mathrm{N}_{2} \mathrm{O}$-induced antinociception. ${ }^{63}$

\section{Tolerance to $\mathrm{N}_{2} \mathrm{O}$ Antinociception}

As with many centrally mediated drug effects, continuous administration of $\mathrm{N}_{2} \mathrm{O}$ results in development of tolerance to the antinociceptive effect of $\mathrm{N}_{2} \mathrm{O}$ in experimental animals ${ }^{39}$ and to the analgesic effect of $\mathrm{N}_{2} \mathrm{O}$ in human subjects. ${ }^{65}$ Studies in different rat strains have provided valuable insight into the development of tolerance to $\mathrm{N}_{2} \mathrm{O}$. The Fischer rat strain exhibits a robust antinociceptive response to $\mathrm{N}_{2} \mathrm{O}$ but does not show acute tolerance, whereas the Lewis rat strain is poorly responsive to $\mathrm{N}_{2} \mathrm{O}$-induced antinociception. ${ }^{66}$ In addi- 
tion to differential sensitivity to $\mathrm{N}_{2} \mathrm{O}$, the Fisher and Lewis rats also differ in neurochemistry and behavioral reactions to other centrally active drugs. ${ }^{67,68}$ Compared to the Fischer rat, the poorly responsive Lewis strain has lower basal levels of endogenous opioid peptides and does not respond with an increase in opioid peptide levels following the administration of morphine. ${ }^{68}$ This is also consistent with findings that maintenance of high levels of opioid peptide by inhibiting enkephalinase enzyme can prevent the development of acute tolerance to $\mathrm{N}_{2} \mathrm{O}$ in rats. ${ }^{69}$

\section{ANXIOLYSIS}

In dentistry, subanesthetic concentrations of $\mathrm{N}_{2} \mathrm{O}$ are routinely used to produce moderate sedation for dental surgery in anxious patients. ${ }^{70}$ Minimal and moderate sedation (or conscious sedation, as was the previous terminology used) is mediated by the administration of agents causing alterations in the level of consciousness, cognition, motor coordination, degree of anxiety, and physiological parameters. It is not defined by specific medications or their doses but instead by the patient's response: the patient must retain the ability to respond purposefully to verbal commands either alone or accompanied by light tactile stimulation. ${ }^{71}$

In pediatric dentistry, $\mathrm{N}_{2} \mathrm{O}$ is an invaluable tool in managing the mildly to moderately anxious child. The ease of its administration, its wide margin of safety, its analgesic and anxiolytic effects, and, most of all, its rapid reversibility make it an ideal drug for use in children. ${ }^{72-75}$ The most recent survey of the active members of the American Academy of Pediatric Dentistry by Houpt $^{76}$ reported that $61 \%$ of 1758 respondents used $\mathrm{N}_{2} \mathrm{O} / \mathrm{O}_{2}$ with other sedative agents. The American Academy of Pediatric Dentistry recognizes nitrous oxide/oxygen inhalation as a safe and effective technique to reduce anxiety, produce analgesia, and enhance effective communication between a patient and health care provider. ${ }^{71}$

There is evidence that the relaxation and relief from anxiety during inhalation of $\mathrm{N}_{2} \mathrm{O}$ is a specific anxiolytic effect that is independent of the analgesic action of $\mathrm{N}_{2} \mathrm{O}$. The mechanisms involved are not yet completely understood.

\section{The Benzodiazepine/GABA Receptor Hypothesis of $\mathrm{N}_{2} \mathrm{O}$ Anxiolysis}

$\mathrm{N}_{2} \mathrm{O}$ evokes patterns of behavioral response that are reminiscent of the effects of benzodiazepines in different animal models of experimental anxiety, including the mouse staircase test, ${ }^{77-79}$ the mouse elevated plus

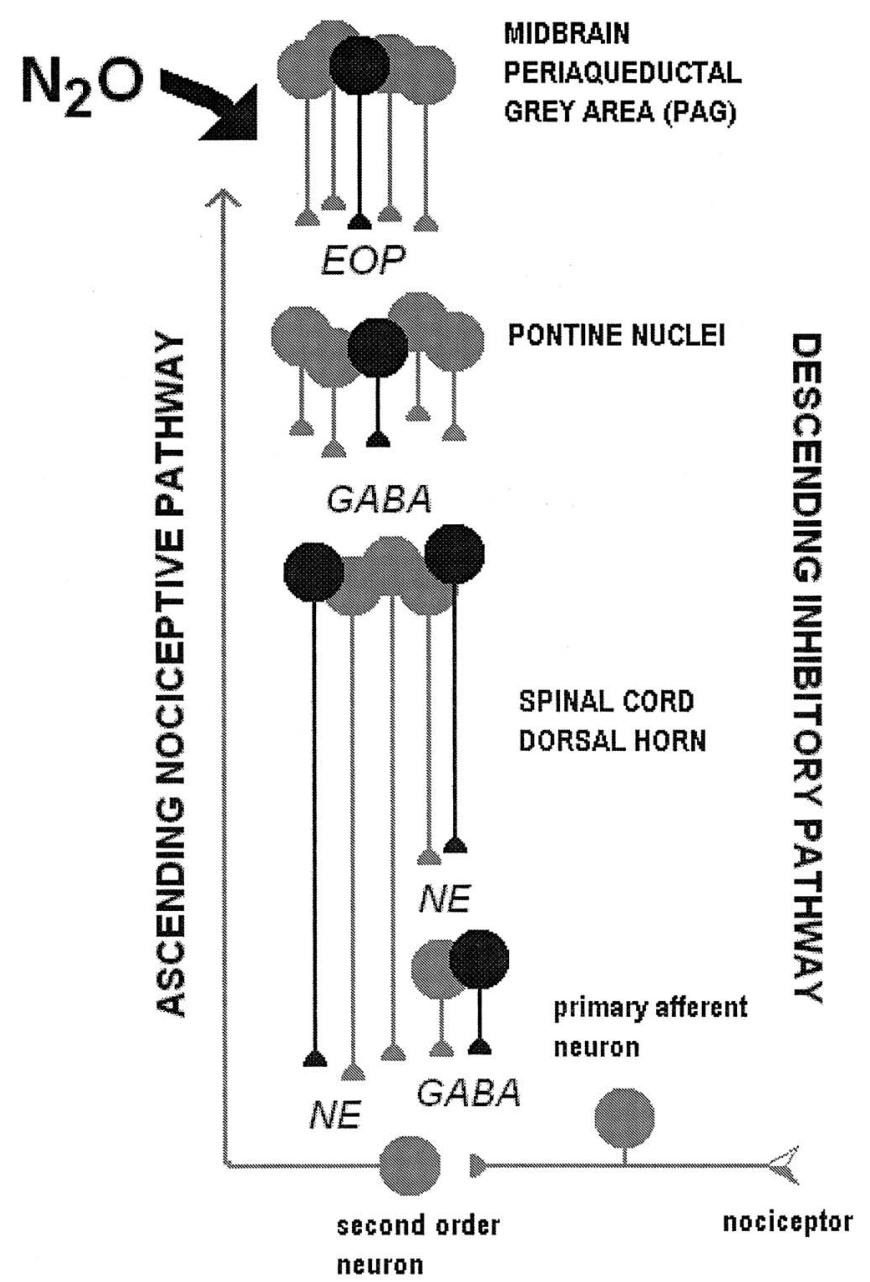

NOCICEPTIVE PROCESSING

Figure 2. Influence of $\mathrm{N}_{2} \mathrm{O}$ on descending inhibitory pathways. $\mathrm{N}_{2} \mathrm{O}$ induces release of endogenous opioid peptides (EOP) that activate opioid receptors on $\gamma$-aminobutyric acid (GABA)-ergic pontine nuclei. This pathway, in turn, activates descending noradrenergic system in the dorsal horn of the spinal cord that directly inhibits or indirectly inhibits (through a GABA interneuron) nociceptive processing at the level of the primary afferent and second-order neurons that transmit sensory signals up the ascending nociceptive pathway.

maze, ${ }^{80}$ the mouse light/dark exploration test, ${ }^{81}$ the mouse hole board, ${ }^{82}$ the rat social interaction test, ${ }^{83}$ and the rat conditioned defensive burying test. ${ }^{84} \mathrm{~N}_{2} \mathrm{O}$ - and benzodiazepine-induced anxiolytic-like behaviors were equally sensitive to antagonism by the benzodiazepine binding site blocker flumazenil. ${ }^{79,83,84}$ Mice that are rendered tolerant to benzodiazepines by daily treatment with escalating doses of chlordiazepoxide are cross-tolerant to the anxiolytic-like behavioral response to $\mathrm{N}_{2} \mathrm{O} .{ }^{79,80}$ These findings strongly implicate that the anxiolytic effect of $\mathrm{N}_{2} \mathrm{O}$ is associated with brain benzodiazepine mechanisms. 


\section{Signaling Pathway That Mediates Anxiolytic-like Activity}

Because benzodiazepines work through facilitation of GABA-ergic inhibitory neurotransmission, research was conducted to determine involvement of $\mathrm{GABA}_{\mathrm{A}}$ receptors in $\mathrm{N}_{2} \mathrm{O}$ anxiolysis. In the light/dark exploration test, $\mathrm{N}_{2} \mathrm{O}$ - and chlordiazepoxide-induced increases in time spent in the light compartment as well as the number of transitions were blocked by the benzodiazepine antagonist flumazenil and the $\mathrm{GABA}_{\mathrm{A}}$ antagonist SR95531 (2-[3-carboxypropyl]-3-amino-6- [4-methoxyphenyll-pyridazinium bromide). ${ }^{81}$ Consistent with the known interaction between benzodiazepine and $\mathrm{GABA}_{\mathrm{A}}$ receptors, these findings indicate that $\mathrm{GABA}_{\mathrm{A}}$ receptors mediate the anxiolytic-like effects caused by chlordiazepoxide and $\mathrm{N}_{2} \mathrm{O}$ activation of benzodiazepine receptors. This is also supported by observations that $\mathrm{N}_{2} \mathrm{O}$ induced depression of visual evoked potentials is antagonized by a benzodiazepine inverse agonist. ${ }^{85}$

$\mathrm{N}_{2} \mathrm{O}$ - and benzodiazepine-induced anxiolytic-like effects in animal models of anxiety are also sensitive to antagonism by inhibition of NOS, a family of enzymes responsible for the synthesis of NO. Studies in the elevated plus maze revealed that the increased open-arm activity produced by $\mathrm{N}_{2} \mathrm{O}$ and chlordiazepoxide was blocked by a nonselective NOS inhibitor; this antagonism was stereoselectively reversed by L-arginine. ${ }^{86,87} \mathrm{In}$ the light/dark exploration test, selective neuronal NOS inhibitors antagonized both $\mathrm{N}_{2} \mathrm{O}$ - and chlordiazepoxideinduced increases in the time spent in the light compartment. ${ }^{81,88}$ The antagonism of $\mathrm{N}_{2} \mathrm{O}$ was duplicated by $\mathrm{NO}$ scavenger hemoglobin ${ }^{89}$ as well as an antisense oligodeoxynucleotide against neuronal NOS. ${ }^{89}$ These findings suggest that NO plays a key role in the anxiolytic signaling mechanism downstream from the benzodiazepine/GABA $\mathrm{A}_{\mathrm{A}}$ receptor complex. ${ }^{88}$ The key role of $\mathrm{NO}$ in anxiolysis was also evidenced by the anxiolyticlike effects of a centrally administered NO donor. ${ }^{90}$

The soluble 3',5'-cyclic guanosine monophosphate (cGMP)-dependent pathway has been identified by many studies as the main signal transduction pathway of NO. ${ }^{42}$ In experiments in the light/dark exploration test, $\mathrm{N}_{2} \mathrm{O}$ anxiolysis was blocked by the guanylyl cyclase inhibitor ODQ (1H-[1,2,4]oxadiazolo[4,3- $\alpha$ ]quinoxalin-1one) and the GMP-dependent protein kinase (PKA)/ cGMP-dependent protein kinase (PKG) inhibitor H8 (N[2-(methyl-amino)ethyl]-5-isoquinoline sulfonamide $\mathrm{HCl}$ ) and was potentiated by the cyclic GMP phosphodiesterase inhibitor zaprinast. ${ }^{91}$ cGMP is known to act upon several different targets: cGMP-dependent protein kinases (PKG), cGMP-fated cation channels, or cGMPregulated phosphodiesterase. ${ }^{92} \mathrm{~N}_{2} \mathrm{O}$-induced anxiolyticlike behavior was significantly attenuated by inhibitors of PKG but not cAMP-dependent protein kinase (PKA). ${ }^{93}$ (See Figure 3)

Although there is evidence that stimulation of $\mathrm{GABA}_{\mathrm{A}}$ receptors activates an anxiolytic signaling pathway that includes an enzyme sequence of NOS, soluble guanylyl cyclase, and PKG, how $\mathrm{N}_{2} \mathrm{O}$ acts at the molecular level to stimulate the $\mathrm{BZ}$ binding site and $\mathrm{GABA}_{\mathrm{A}}$ receptor is not yet known. In a manner similar to how $\mathrm{N}_{2} \mathrm{O}$ activates opioid receptors, it is plausible that $\mathrm{N}_{2} \mathrm{O}$ may induce neuronal release of endogenous benzodiazepine factors that then stimulate the $\mathrm{GABA}_{\mathrm{A}}$ receptor.

\section{ANESTHESIA}

$\mathrm{N}_{2} \mathrm{O}$ has a well-known role in medical history because it was the first drug used for surgical anesthesia. Despite its limited anesthetic potency, $\mathrm{N}_{2} \mathrm{O}$ is the most widely used general anesthetic agent. With a minimum alveolar concentration of $104 \%$ in humans, $\mathrm{N}_{2} \mathrm{O}$ by itself would require high volume percentage and hyperbaric conditions to achieve anesthesia in $50 \%$ of subjects. ${ }^{94}$ Therefore, because of its low potency, in clinical practice, $\mathrm{N}_{2} \mathrm{O}$ is generally used to reduce the minimum alveolar concentration of a second inhalation agent for anesthesia and increase the rate of induction (ie, the second gas effect ${ }^{95}$ ) and to provide or augment the analgesic component of general anesthesia.

General anesthetics like $\mathrm{N}_{2} \mathrm{O}$ have long been hypothesized to act in a nonspecific manner on neuronal membranes, alter membrane fluidity, and/or influence ion channels. But more recently, it has been suggested that general anesthetics might act on one or more superfamilies of ligand-gated ion channels that include $\mathrm{GABA}_{\mathrm{A}}$, glycine, nicotinic acetylcholine, 5-hydroxytryptamine ${ }_{3}$, and glutamate receptors. ${ }^{96,97}$ Among the ligand-gated ion channels, the $\mathrm{GABA}_{\mathrm{A}}$ receptor is considered to be a prime target of volatile and intravenous anesthetics. Several anesthetics are known to potentiate the activity of GABA at inhibitory $\mathrm{GABA}_{\mathrm{A}}$ receptor. $\mathrm{N}_{2} \mathrm{O}$ itself has been reported to affect various ligand-gated ion channels. ${ }^{98-100}$

$\mathrm{N}$-methyl-D-aspartate (NMDA)-type glutamate receptors have recently emerged as a possible target of inhalation anesthetic drugs. Studies in cultured rat hippocampal neurons revealed that $\mathrm{N}_{2} \mathrm{O}$ inhibited NMDAactivated currents in a dose-dependent manner but had no effect on GABA-activated currents. ${ }^{101}$ Consistent with NMDA antagonism, $\mathrm{N}_{2} \mathrm{O}$ is reported to up-regulate binding of NMDA radioligand in the cerebral cortex. ${ }^{102}$ $\mathrm{N}_{2} \mathrm{O}$ also inhibited excitotoxic neurodegeneration that is mediated through NMDA receptors. Similar to other NMDA antagonists, the neurotoxic effect of $\mathrm{N}_{2} \mathrm{O}$ is agedependent and is sensitive to attenuation by GABA-erg- 


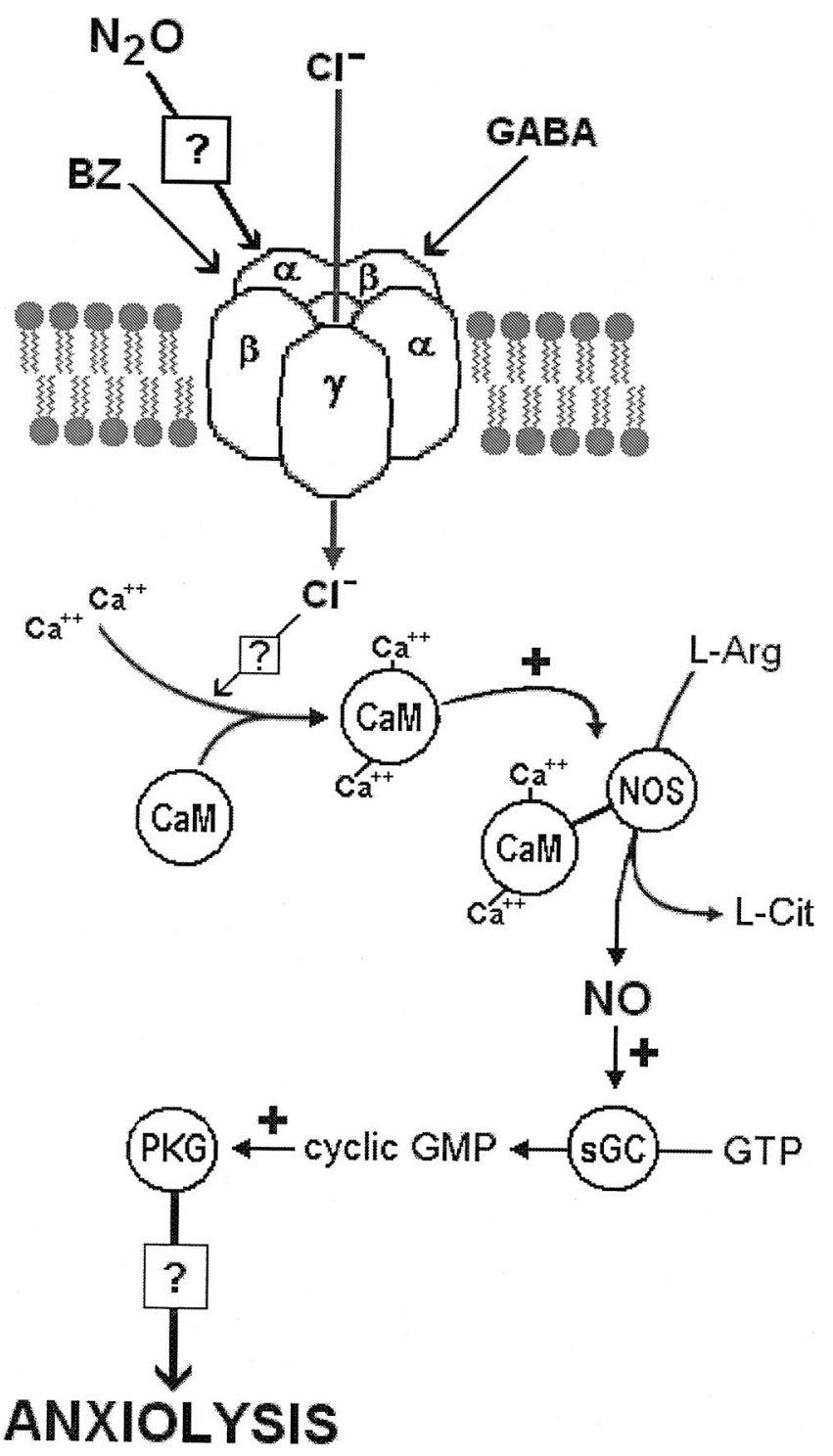

Figure 3. Mechanism of $\mathrm{N}_{2} \mathrm{O}$-induced anxiolysis. $\mathrm{N}_{2} \mathrm{O}$ is thought to cause activation of the benzodiazepine (BZ) binding site as its effects are blocked by flumazenil. This action facilitates $\gamma$-aminobutyric acid (GABA) activation of its binding site, resulting in chloride ion influx. The increased chloride ion concentration in the neuron might cause activation of calmodulin (CaM), which then activates the enzyme nitric oxide synthase (NOS). NOS converts the amino acid L-arginine (L-Arg) to Lcitrulline (L-Cit) and NO, which stimulates the enzyme soluble guanylyl cyclase producing the second messenger cyclic guanosine monophosphate (cyclic GMP). The cyclic GMP, in turn, stimulates a cyclic GMP-dependent protein kinase (PKG) that leads to the anxiolytic drug effect.

ic drugs. ${ }^{103,104}$ It is suggested that a common property of NMDA receptor antagonism may underlie the similar pharmacological profiles of $\mathrm{N}_{2} \mathrm{O}$ and ketamine, an intravenous dissociative anesthetic. The 2 drugs, in fact, produce synergistic neurotoxicity when used together. ${ }^{105}$

\section{SUMMARY}

It is apparent from the above discussion that $\mathrm{N}_{2} \mathrm{O}$ has multiple mechanisms of action that underlie its varied pharmacological properties. Current research indicates that the analgesic effect of $\mathrm{N}_{2} \mathrm{O}$ appears to be initiated by stimulated neuronal release of endogenous opioid peptides, with subsequent activation of opioid receptors and descending GABA and noradrenergic pathways that modulate nociceptive processing at the spinal level. The anxiolytic effect of $\mathrm{N}_{2} \mathrm{O}$ involves activation of the $\mathrm{GABA}_{\mathrm{A}}$ receptor through the benzodiazepine binding site, although whether $\mathrm{N}_{2} \mathrm{O}$ acts directly or indirectly upon the latter targets remains uncertain. The anxiolytic pathway that is stimulated includes a segment that involves a sequence of 3 key enzymes, NOS, soluble guanylyl cyclase, and PKG. The anesthetic effect of $\mathrm{N}_{2} \mathrm{O}$ appears to be caused by inhibition of NMDA glutamate receptors and removing its excitatory influence in the nervous system.

\section{REFERENCES}

1. Greene NM. A consideration of factors in the discovery of anesthesia and their effects on its development. Anesthesiology. 1971;35:515-522.

2. Jastak JT. Nitrous oxide in dental practice. Int Anesthesiol Clin. 1989;27:92-97.

3. Eger El. Nitrous Oxide/ $\mathrm{N}_{2} \mathrm{O}$. 2nd ed. New York, Elsevier, 1985.

4. Dundee JW, Moore J. Alterations in response to somatic pain associated with anaesthesia. IV. The effect of subanaesthetic concentrations of inhalation agents. $\mathrm{Br} J$ Anaesth. 1960;32:453-459.

5. Rosen MA. Nitrous oxide for relief of labor pain. a systematic review. Am J Obstet Gynecol. 2002;186:110126.

6. Parlow JL, Milne B, Tod DA, Stewart GI, Griffiths JM, Dudgeon DJ. Self-administered nitrous oxide for the management of incident pain in terminally ill patients: a blinded case series. Palliat Med. 2005;19:3-8.

7. Katz J. Pre-emptive analgesia: evidence, current status and future directions. Eur J Anaesthesiol. 1995; Suppl 10: 8-13.

8. Cleary AG, Ramanan AV, Baildam E, Birch A, Sills JA, Davidson JE. Nitrous oxide analgesia during intra-articular injection for juvenile idiopathic arthritis. Arch Dis Child. 2002;86:416-418.

9. Gerhardt RT, King KM, Wiegert RS. Inhaled nitrous oxide versus placebo as an analgesic and anxiolytic adjunct to peripheral intravenous cannulation. Am J Emerg Med. 2001; 19:492-494.

10. Harding TA, Gibson JA. The use of inhaled nitrous oxide for flexible sigmoidoscopy: a placebo-controlled trial. Endoscopy. 2000;32:457-460.

11. Forbes GM, Collins BJ. Nitrous oxide for colonosco- 
py: a randomized controlled study. Gastrointest Endosc. 2000;51:271-277.

12. Cook HL, Newsom RS, Mensah E, Saeed M, James D, Ffytche TJ. Entonox as an analgesic agent during panretinal photocoagulation. $\mathrm{Br} J$ Ophthalmol. 2002;86:11071108.

13. Masood J, Shah N, Lanes T, Andrews H, Simpson P, Barua JM. Nitrous oxide (entonox) inhalation and tolerance of transrectal ultrasound guided prostate biopsy: a double-blind randomized controlled study. J Urol. 2002;168:116-120.

14. Baskett PJ. Use of Entonox in the ambulance service. Br Med J. 1970;2:41-43.

15. Dollfus C, Annequin D, Adam M, et al. Analgésie par le protoxyde d'azote pour la pratique de gestes douloureux en hémato oncologie pédiatrique. Ann Pediatr (Paris). 1995;42: $115-121$

16. Annequin D, Hamon R. Utilisation du Protoxyde d'Azote Pour les Actes Douloureux en Pédiatrie. Paris: SPARADRAP; 1995.

17. Chapman WP, Arrowood JA, Beecher HK. The analgetic effects of low concentrations of nitrous oxide compared in man with morphine sulphate. J Clin Invest. 1943;22:871875.

18. Berkowitz BA, Ngai SH, Finck AD. Nitrous oxide "analgesia": resemblance to opiate action. Science. 1976;194: 967-968.

19. Berkowitz BA, Finck AD, Ngai SH. Nitrous oxide analgesia: reversal by naloxone and development of tolerance. $J$ Pharmacol Exp Ther. 1977;203:539-547.

20. Chapman CR, Benedetti C. Nitrous oxide effects on cerebral evoked potential to pain: partial reversal with a narcotic antagonist. Anesthesiology. 1979;51:135-138.

21. Gillman MA, Kok L, Lichtigfeld FJ. Paradoxical effect of naloxone on nitrous oxide analgesia in man. Eur $J$ Pharmacol. 1980;61:175-177.

22. Lawrence D, Livingston A. Opiate-like analgesic activity in general anaesthetics. Br J Pharmacol. 1981;73:435442.

23. Yang JC, Clark WC, Ngai SH. Antagonism of nitrous oxide analgesia by naloxone in man. Anesthesiology. 1980; 52:414-417.

24. Lewis VA, Gebhart GF. Evaluation of the periaqueductal central gray (PAG) as a morphine-specific locus of action and examination of morphine-induced and stimulation-produced analgesia at coincident PAG loci. Brain Res. 1977;124: 283-303.

25. Zuniga J, Joseph S, Knigge K. Nitrous oxide analgesia: partial antagonism by naloxone and total reversal after periaqueductal gray lesions in the rat. Eur $J$ Pharmacol. 1987; 142:51-60.

26. Hodges BL, Gagnon MJ, Gillespie TR, et al. Antagonism of nitrous oxide antinociception in the rat hot plate test by site-specific mu and epsilon opioid receptor blockade. $J$ Pharmacol Exp Ther. 1994;269:596-600.

27. Fang F, Guo TZ, Davies MF, Maze M. Opiate receptors in the periaqueductal gray mediate analgesic effect of nitrous oxide in rats. Eur J Pharmacol. 1997;336:137-141.

28. Emmanouil DE, Ohgami Y, Chung E, Han S, Quock
RM. Nitrous oxide $\left(\mathrm{N}_{2} \mathrm{O}\right)$ antinociception in the mouse abdominal constriction test is mediated by opioid receptors in the periaqueductal gray region of the brain. Proc West Pharmacol Soc. 2004;47:151

29. Fujinaga M, Maze M. Neurobiology of nitrous oxideinduced antinociceptive effects. Mol Neurobiol. 2002;25: 167-189.

30. Quock RM, Graczak LM. Influence of narcotic antagonist drugs upon nitrous oxide analgesia in mice. Brain Res. 1988;440:35-41.

31. Quock RM, Vaughn LK. Nitrous oxide: mechanism of its analgesic action. Analgesia. 1995;1:151-159.

32. Quock RM, Mueller J. Protection by U-50,488H against $\beta$-chlornaltrexamine antagonism of nitrous oxide antinociception in mice. Brain Res. 1991;549:162-164.

33. Quock RM, Best JA, Chen DC, Vaughn LK, Portoghese PS, Takemori AE. Mediation of nitrous oxide analgesia in mice by spinal and supraspinal kappa-opioid receptors. Eur $J$ Pharmacol 1990;175:97-100. Erratum in: Eur $J$ Pharmacol. 1990;187:564.

34. Branda EM, Ramza JT, Cahill FJ, Tseng LF, Quock RM. Role of brain dynorphin in nitrous oxide antinociception in mice. Pharmacol Biochem Behav. 2000;65:217-221.

35. Cahill FJ, Ellenberger EA, Mueller JL, Tseng LF, Quock RM. Antagonism of nitrous oxide antinociception in mice by intrathecally administered antisera to endogenous opioid peptides. J Biomed Sci. 2000;7:299-303.

36. Berkowitz BA, Finck AD, Hynes MD, Ngai SH. Tolerance to nitrous oxide analgesia in rats and mice. Anesthesiology. 1979;51:309-312.

37. Quock RM, Kouchich FJ, Tseng LF. Does nitrous oxide induce release of brain opioid peptides? Pharmacology. 1985;30:95-99.

38. Zuniga JR, Joseph SA, Knigge KM. The effects of nitrous oxide on the central endogenous pro-opiomelanocortin system in the rat. Brain Res. 1987;420:57-65.

39. Zuniga JR, Joseph SA, Knigge KM. The effects of nitrous oxide on the secretory activity of pro-opiomelanocortin peptides from basal hypothalamic cells attached to cytodex beads in a superfusion in vitro system. Brain Res. 1987;420: 66-72.

40. Tseng LF, Collins KA. Spinal involvement of both dynorphin $\mathrm{A}$ and Met-enkephalin in the antinociception induced by intracerebroventricularly administered bremazocine but not morphine in the mouse. $J$ Pharmacol Exp Ther. 1993;266: 1430-1438.

41. Culotta E, Koshland DE Jr. NO news is good news. Science. 1992;258:1862.

42. Prast H, Philippu A. Nitric oxide as modulator of neuronal function. Prog Neurobiol. 2001;64:51-68.

43. McDonald CE, Gagnon MJ, Ellenberger EA, et al. Inhibitors of nitric oxide synthesis antagonize nitrous oxide antinociception in mice and rats. $J$ Pharmacol Exp Ther. 1994; 269:601-608.

44. Ishikawa M, Quock RM. Role of nitric-oxide synthase isoforms in nitrous oxide antinociception in mice. $J$ Pharmacol Exp Ther. 2003; 306:484-489.

45. Li S, Bieber AJ, Quock RM. Antagonism of nitrous 
oxide antinociception in mice by antisense oligodeoxynucleotide directed against neuronal nitric oxide synthase enzyme. Behav Brain Res. 2004; 52:361-363.

46. Hara S, Kuhns ER, Ellenberger EA, et al. Involvement of nitric oxide in intracerebroventricular $\beta$-endorphin-induced neuronal release of methionine-enkephalin. Brain Res. 1995; 675:190-194.

47. Quock RM, Mueller JL, Vaughn LK. Strain-dependent differences in responsiveness of mice to nitrous oxide $\left(\mathrm{N}_{2} \mathrm{O}\right)$ antinociception. Brain Res. 1993;614:52-56.

48. Quock RM, Mueller JL, Vaughn LK, Belknap JK. Nitrous oxide antinociception in BXD recombinant inbred mouse strains and identification of quantitative trait loci. Brain Res. 1996;725:23-29.

49. Ishikawa M, Quock RM. $\mathrm{N}_{2} \mathrm{O}$ stimulates NOS enzyme activity in C57BL/ 6 but not DBA/2 mice. Brain Res. 2003; 976:262-263.

50. Henry ED, Ohgami Y, Li S, Chung E, Quock RM. Correlation of inbred mouse sensitivity to nitrous oxide antinociception with brain nitric oxide synthase activity following exposure to nitrous oxide. Pharmacol Biochem Behav. 2005; 81:764-768.

51. Mueller JL, Ellenberger EA, Vaughn LK, Belknap JK, Quock RM. Detection and mapping of quantitative trait loci that determine responsiveness of mice to nitrous oxide antinociception. Neuroscience. 2004;123:743-749.

52. Lee CGL, Gregg AR, O'Brien WE. Localization of the neuronal form of nitric oxide synthase to mouse chromosome 5. Mamm Genome. 1995;6:56-57.

53. Fujinaga M, Maze M. Neurobiology of nitrous oxideinduced antinociceptive effects. Mol Neurobiol. 2002;25: 167-189.

54. Zhang C, Davies MF, Guo TZ, Maze M. The analgesic action of nitrous oxide is dependent on the release of norepinephrine in the dorsal horn of the spinal cord. Anesthesiology. 1999;91:1401-1407.

55. Guo TZ, Poree L, Golden W, Stein J, Fujinaga M, Maze M. Antinociceptive response to nitrous oxide is mediated by supraspinal opiate and spinal alpha ${ }_{2}$ adrenergic receptors in the rat. Anesthesiology. 1996;85:846-852.

56. Guo TZ, Davies MF, Kingery WS, Patterson AJ, Limbird LE, Maze M. Nitrous oxide produces antinociceptive response via alpha $_{2 \mathrm{~B}}$ and/or alpha $\mathrm{a}_{2 \mathrm{C}}$ adrenoceptor subtypes in mice. Anesthesiology. 1999;90:470-476.

57. Orii R, Ohashi Y, Guo T, et al. Evidence for the involvement of spinal cord alpha ${ }_{1}$ adrenoceptors in nitrous oxide-induced antinociceptive effects in Fischer rats. Anesthesiology. 2002;97:1458-1465.

58. Fitzgerald M, Koltzenburg M. The functional development of descending inhibitory pathways in the dorsolateral funiculus of the newborn rat spinal cord. Brain Res. 1986; 389:261-270.

59. Fitzgerald M, Shaw A, MacIntosh N. Postnatal development of the cutaneous flexor reflex: comparative study of preterm infants and newborn rat pups. Dev Med Child Neurol. 1988;30:520-526.

60. Fujinaga M, Doone R, Davies MF, Maze M. Nitrous oxide lacks the antinociceptive effect on the tail flick test in newborn rats. Anesth Analg. 2000;91:6-10.

61. Ohashi Y, Stowell JM, Nelson LE, Hashimoto T, Maze M, Fujinaga M. Nitrous oxide exerts age-dependent antinociceptive effects in Fischer rats. Pain. 2002;100:7-18.

62. Orii R, Ohashi Y, Halder S, Giombini M, Maze M, Fujinaga M. GABAergic interneurons at supraspinal and spinal levels differentially modulate the antinociceptive effect of nitrous oxide in Fischer rats. Anesthesiology. 2003;98:12231230.

63. Ohashi Y, Guo T, Orii R, Maze M, Fujinaga M. Brain stem opioidergic and GABAergic neurons mediate the antinociceptive effect of nitrous oxide in Fischer rats. Anesthesiology. 2003;99:947-954.

64. Hashimoto T, Maze M, Ohashi Y, Fujinaga M. Nitrous oxide activates GABAergic neurons in the spinal cord in Fischer rats. Anesthesiology. 2001;95:463-469.

65. Rupreht J, Dworacek B, Bonke B, Dzoljic MR, van Eijndhoven $\mathrm{JH}$, de Vlieger M. Tolerance to nitrous oxide in volunteers. Acta Anaesthesiol Scand. 1985;29:635-638

66. Fender C, Fujinaga M, Maze M. Strain differences in antinociceptive effect of nitrous oxide on tail flick test in rats. Anesth Analg. 2000;90:195-199.

67. Beitner-Johnson D, Guitart X, Nestler EJ. Dopaminergic reward regions of Lewis and Fischer rats display different levels of tyrosine hydroxylase and other morphine- and cocaine-regulated phosphoproteins. Brain Res. 1991;561: 147-150.

68. Nylander I, Vlaskovska M, Terenius L. Brain dynorphin and enkephalin systems in Fischer and Lewis rats: effects of morphine tolerance and withdrawal. Brain Res. 1995;683: 25-35.

69. Rupreht J, Dworacek B, Ducardus R, Schmitz PI, Dzoljic MR. The involvement of the central cholinergic and endorphinergic systems in the nitrous oxide withdrawal syndrome in mice. Anesthesiology. 1983;58:524-526.

70. Jackson DL, Johnson BS. Inhalational and enteral conscious sedation for the adult dental patient. Dent Clin North Am. 2002;46:781-802.

71. American Academy of Pediatric Dentistry. Clinical guideline on the elective use of minimal, moderate, and deep sedation and general anesthesia for pediatric dental patients. Pediatr Dent. 2004;25:95-103.

72. Malamed SF. An update on pain and anxiety control in pediatric dentistry. Part II. Inhalation sedation and local anesthesia. Alpha Omegan. 1979;72:29-33.

73. Wilson S. A survey of the American Academy of Pediatric Dentistry membership: nitrous oxide and sedation. $\mathrm{Pe}$ diatr Dent. 1996;18:287-293.

74. Paterson SA, Tahmassebi JF. Paediatric dentistry in the new millennium: 3. Use of inhalation sedation in paediatric dentistry. Dent Update. 2003;30:350-356, 358.

75. Houpt MI, Limb R, Livingston RL. Clinical effects of nitrous oxide conscious sedation in children. Pediatr Dent. 2004;26:29-36.

76. Houpt M. Project USAP 2000-use of sedative agents by pediatric dentists: a 15-year follow-up survey. $\mathrm{Pe}$ diatr Dent. 2002;24:289-294. 
77. Quock RM, Wojcechowskyj JA, Emmanouil DE. Comparison of nitrous oxide, morphine and diazepam effects in the mouse staircase test. Psychopharmacology (Berl). 1987; 92:324-326.

78. Emmanouil DE, Quock RM. Effects of benzodiazepine agonist, inverse agonist and antagonist drugs in the mouse staircase test. Psychopharmacology (Berl). 1990;102:95-97.

79. Quock RM, Emmanouil DE, Vaughn LK, Pruhs RJ. Benzodiazepine receptor mediation of behavioral effects of nitrous oxide in mice. Psychopharmacology (Berl). 1992;107: 310-314.

80. Emmanouil DE, Johnson CH, Quock RM. Nitrous oxide anxiolytic effect in mice in the elevated plus maze: mediation by benzodiazepine receptors. Psychopharmacology (Berl). 1994;115:167-172.

81. Li S, Quock RM. Comparison of $\mathrm{N}_{2} \mathrm{O}$ - and chlordiazepoxide-induced behaviors in the light/dark exploration test. Pharmacol Biochem Behav. 2001;68:789-796.

82. Czech DA, Green DA. Anxiolytic effects of nitrous oxide in mice in the light-dark and holeboard exploratory tests. Psychopharmacology (Berl). 1992;109:315-320.

83. Quock RM, Wetzel PJ, Maillefer RH, Hodges BL, Curtis $\mathrm{BA}$, Czech DA. Benzodiazepine receptor-mediated behavioral effects of nitrous oxide in the rat social interaction test. Pharmacol Biochem Behav. 1993;46:161-165.

84. Czech DA, Quock RM. Nitrous oxide induces an anxiolytic-like effect in the conditioned defensive burying paradigm, which can be reversed with a benzodiazepine receptor blocker. Psychopharmacology (Berl). 1993;113:211-216.

85. Dzoljic M, Erdmann W, Dzoljic MR. Visual evoked potentials and nitrous oxide-induced neuronal depression: role for benzodiazepine receptors. Br J Anaesth. 1996;77:522-525.

86. Quock RM, Nguyen E. Possible involvement of nitric oxide in chlordiazepoxide-induced anxiolysis in mice. Life Sci. 1992;51:PL255-260.

87. Caton PW, Tousman SA, Quock RM. Involvement of nitric oxide in nitrous oxide anxiolysis in the elevated plusmaze. Pharmacol Biochem Behav. 1994;48:689-692.

88. Li S, Ohgami Y, Dai Y, Quock RM. Antagonism of nitrous oxide-induced anxiolytic-like behavior in the mouse light/dark exploration procedure by pharmacologic disruption of endogenous nitric oxide function. Psychopharmacology (Berl). 2003;166:366-372.

89. Li S, Dai Y, Quock RM. Antisense knockdown of neuronal nitric oxide synthase antagonizes nitrous oxide-induced behavior. Brain Res. 2003; 968:167-170.

90. Li S, Quock RM. Effects of a nitric oxide donor on behavior and interaction with nitrous oxide in the mouse light/ dark exploration test. Eur J Pharmacol. 2002;447:75-78.

91. Li S, Chung E, Quock RM. Role of cyclic GMP in nitrous-oxide-induced anxiolytic-like behavior in the mouse light-dark exploration test. Behav Neurosci. 2004;118:648652.

92. Denninger JW, Marletta MA. Guanylate cyclase and the $\cdot \mathrm{NO} / \mathrm{cGMP}$ signaling pathway. Biochim Biophys Acta. 1999;1411:334-350.

93. Li S, Doss JC, Hardee EJ, Quock RM. Involvement of cyclic GMP-dependent protein kinase in nitrous oxide-induced anxiolytic-like behavior in the mouse light/dark exploration test. Brain Res. 2005;1038:113-117.

94. Hornbein TF, Eger EI 2nd, Winter PM, Smith G, Wetstone $\mathrm{D}$, Smith $\mathrm{KH}$. The minimum alveolar concentration of nitrous oxide in man. Anesth Analg. 1982;61:553-556.

95. Epstein RM, Rackow H, Salanitre E, Wolf GL. Influence of the concentration effect on the uptake of anesthetic mixtures: the second gas effect. Anesthesiology. 1964;25: 364-371.

96. Franks NP, Lieb WR. Do general anaesthetics act by competitive binding to specific receptors? Nature. 1984;310: 599-601.

97. Krasowski MD, Harrison NL. General anaesthetic actions on ligand-gated ion channels. Cell Mol Life Sci. 1999; 55:1278-1303.

98. Wachtel RE. Relative potencies of volatile anesthetics in altering the kinetics of ion channels in BC3H1 cells. $J$ Pharmacol Exp Ther. 1995;274:1355-1361.

99. Dzoljic M, Van Duijn B. Nitrous oxide-induced enhancement of gamma-aminobutyric acid $_{\mathrm{A}}$-mediated chloride currents in acutely dissociated hippocampal neurons. Anesthesiology. 1998;88:473-480.

100. Yamakura T, Harris RA. Effects of gaseous anesthetics nitrous oxide and xenon on ligand-gated ion channels. Comparison with isoflurane and ethanol. Anesthesiology. 2000; 93:1095-1101.

101. Jevtovic-Todorovic V, Todorovic SM, Mennerick S, Powell S, Dikranian K, Benshoff N, Zorumski CF, Olney JW. Nitrous oxide (laughing gas) is an NMDA antagonist, neuroprotectant and neurotoxin. Nature Med. 1998;4:460-463.

102. Sommer N, Romano C, Jevtovic-Todorovic V. Chronic exposure to nitrous oxide increases [ $\left.{ }^{3} \mathrm{H}\right] \mathrm{MK} 801$ binding in the cerebral cortex, but not in the hippocampus of adult mice. Ann N Y Acad Sci. 2005;1053:301-308.

103. Jevtovic-Todorovic V, Wozniak DF, Benshoff ND, Olney JW. A comparative evaluation of the neurotoxic properties of ketamine and nitrous oxide. Brain Res. 2001;895:264267.

104. Jevtovic-Todorovic V, Beals J, Benshoff N, Olney JW. Prolonged exposure to inhalational anesthetic nitrous oxide kills neurons in adult rat brain. Neuroscience. 2003;122:609616.

105. Jevtovic-Todorovic V, Benshoff N, Olney JW. Ketamine potentiates cerebrocortical damage induced by the common anaesthetic agent nitrous oxide in adult rats. $\mathrm{Br} J$ Pharmacol. 2000;130:1692-1698. 